\title{
Novel PPP1CB-ALK fusion protein in a high-grade glioma of infancy
}

\author{
Yasmin Aghajan, ${ }^{1}$ Michael L Levy, ${ }^{2}$ Denise M Malicki, ${ }^{3}$ John Ross Crawford ${ }^{4}$
}

'University of California, San Diego, School of Medicine, La Jolla, California, USA

${ }^{2}$ Department of Neurosurgery, University of California San Diego, San Diego, California, USA

${ }^{3}$ Department of Pathology, Rady Children's Hospital University of California San Diego, San Diego, California, USA

${ }^{4}$ Department of Neurosciences and Pediatrics, University of California San Diego, San Diego, California, USA

Correspondence to Dr John Ross Crawford, jrcrawford@ucsd.edu

Accepted 2 August 2016

\section{(a) CrossMark}

To cite: Aghajan $Y$, Levy ML, Malicki DM, et al. BMJ Case Rep Published online: [please include Day Month Year] doi:10.1136/ bcr-2016-217189

\section{DESCRIPTION}

A 3-month-old previously healthy girl presented to the hospital with sudden onset altered mental status and cardiopulmonary arrest. Her right pupil was fixed and dilated. Emergent CT scan showed a massive $10.2 \mathrm{~cm}$ hyperdense lesion occupying the right cerebral hemisphere with areas of acute haemorrhage causing subfalcine, uncal and inferior cerebellar herniation with obstructive hydrocephalus and diffuse cerebral oedema (figure 1). Emergent craniotomy was performed for evacuation of the haematoma and gross total resection of the mass in the absence of preoperative MRI. Neuropathology revealed a malignant glial tumour with prominent endothelial proliferation (figure 2). Molecular analysis of the tumour demonstrated a novel PPP1CB-ALK fusion protein. Given the patient's young age and gross total resection, the decision was made not to proceed with chemotherapy. The child remains disease-free at 3 years postdiagnosis with significant motor and neurocognitive delays.

Anaplastic lymphoma kinase (ALK) is a receptor tyrosine kinase first discovered in anaplastic large cell lymphomas. ${ }^{1}$ ALK fusion proteins are oncogenic, as they activate intracellular signalling cascades such as the Ras-ERK, JAK3-STAT3 and PI3K-Akt pathways, ${ }^{1}$ and PPP1CB, a serine/threonine phosphatase, has been implicated in activating those pathways. ${ }^{2}$ The EML4-ALK translocation is

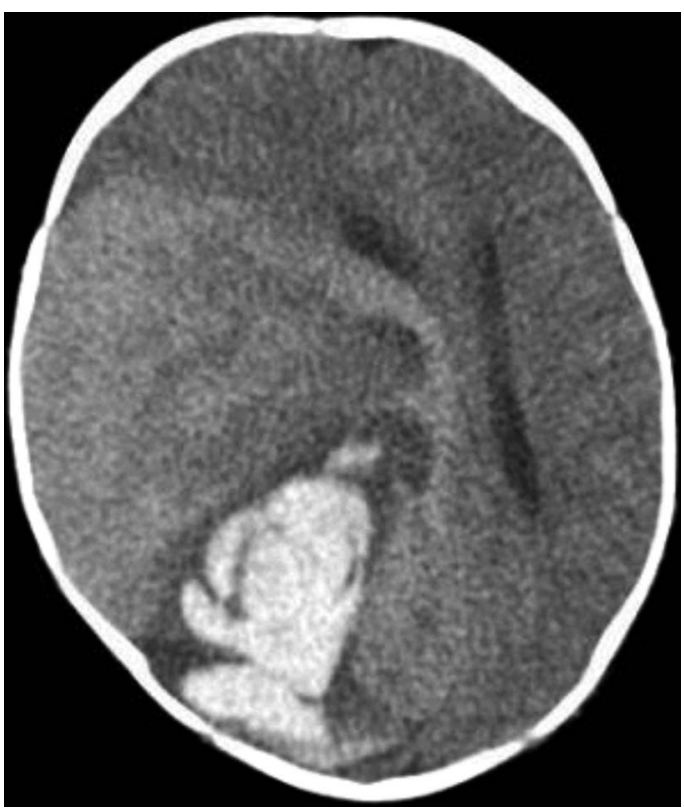

Figure 1 Axial CT image at presentation showing large hyperdense lesion in right cerebral hemisphere with areas of acute haemorrhage, vasogenic oedema and midline shift.

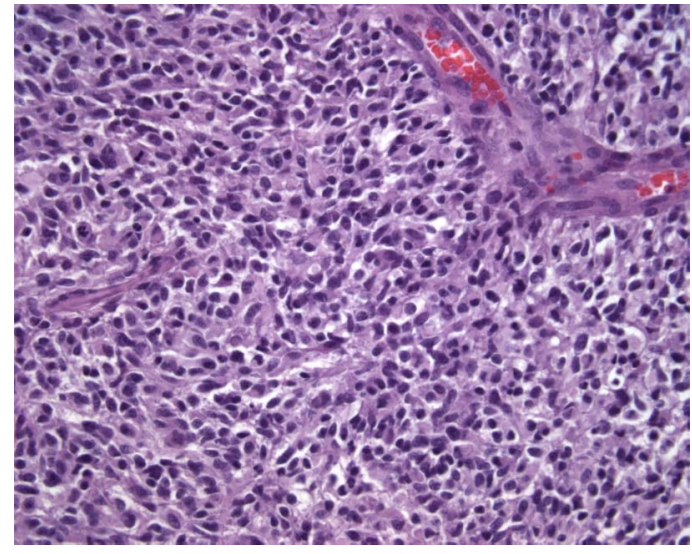

Figure 2 Neuropathology reveals a hypercellular glial tumour with pleomorphic nuclei and endothelial proliferation consistent with a high-grade glioma $(\times 400)$.

the more prevalent ALK mutation in solid cancers, present in 6\% of non-small cell lung cancers. However, ALK fusion proteins have not classically been implicated in primary CNS solid tumours, making this high-grade glioma of infancy a rare and unique case. In conclusion, our findings revealed the first PPP1CB-ALK fusion protein mutation in a primary CNS tumour.

\section{Learning points}

- Anaplastic lymphoma kinase (ALK) fusion proteins are classically implicated in anaplastic large cell lymphoma and non-small cell lung cancer but not in primary CNS solid tumours.

- This case of high-grade glioma of infancy revealed a novel PPP1CB-ALK fusion protein successfully treated with surgery alone.

- Further studies are necessary to understand the role of ALK fusion proteins in the pathogenesis and treatment of CNS neoplasms.

Twitter Follow Yasmin Aghajan at @yaghajan

Contributors YA, JRC, MLL and DMM were all involved in analysis and interpretation of this case. All authors have made substantial contributions and were involved in drafting and revising this work. All authors have reviewed the case report and agree to its content prior to submission.

Competing interests None declared.

Patient consent Obtained.

Provenance and peer review Not commissioned; externally peer reviewed. 


\section{REFERENCES}

1 Chiarle R, Voena C, Ambrogio C, et al. The anaplastic lymphoma kinase in the pathogenesis of cancer. Nat Rev Cancer 2008;8:11-23.
2 Cho YL, Min JK, Roh KM, et al. Phosphoprotein phosphatase 1CB (PPP1CB), a novel adipogenic activator, promotes 3T3-L1 adipogenesis. Biochem Biophys Res Commun 2015;467:211-17.

Copyright 2016 BMJ Publishing Group. All rights reserved. For permission to reuse any of this content visit http://group.bmj.com/group/rights-licensing/permissions.

BMJ Case Report Fellows may re-use this article for personal use and teaching without any further permission.

Become a Fellow of BMJ Case Reports today and you can:

- Submit as many cases as you like

- Enjoy fast sympathetic peer review and rapid publication of accepted articles

- Access all the published articles

- Re-use any of the published material for personal use and teaching without further permission

For information on Institutional Fellowships contact consortiasales@bmjgroup.com

Visit casereports.bmj.com for more articles like this and to become a Fellow 